Editors' Note: In reference to "Practice variability in brain death determination: A call to action," Drs. Rady and Verheijde and author Frank further discuss the need to decouple brain death determination from organ procurement. Dr. Gilbert questions the timing of the development of NMDA receptor limbic encephalitis in the case presented in "Herpes simplex virus-1 encephalitis can trigger anti-NMDA receptor encephalitis: Case report." Authors Leypoldt and Dalmau respond.

—Megan Alcauskas, MD, and Robert C. Griggs, MD

\section{PRACTICE VARIABILITY IN BRAIN DEATH DETERMINATION: A CALL TO ACTION}

Mohamed Y. Rady, Joseph L. Verheijde, Phoenix: Shappell et al. ${ }^{1}$ described practice variability in brain death determination (BDD) in heart-beating organ donors. We would like to raise 3 concerns.

First, the criterion of unresponsiveness to external stimuli does not necessarily prove the lack of either internal or external awareness. ${ }^{2}$ Practice variability in ascertaining unresponsiveness further increases the risk of residual awareness and nociception during procurement since general anesthesia is generally withheld in heart-beating donors.

Second, the accepted medical standards stipulated by Shappell et al. ${ }^{1}$ should confirm irreversibility of cessation of all functions of the whole brain. However, the American Academy of Neurology (AAN) has assigned evidence level " $U$ " to several recommendations in the updated BDD guidelines. ${ }^{3}$ Generally, the Institute of Medicine requires the recommendations to be supported by a much higher level of evidence to be trustworthy. ${ }^{4}$

Third, the collaborative partnership of procurement professionals with the medical team (team-huddling) starts early in the course of inpatient care before making end-of-life decisions and BDD. ${ }^{5}$ There are no data on the influence of team-huddling on either end-of-life decision-making or BDD in potential donors.

The call for improvement in education, documentation, and compliance may not be sufficient to enhance the trustworthiness in BDD and organ donation.

Author Response: Jeffrey I. Frank, Chicago: Drs. Rady and Verheijde have made several important comments. Their concerns about clinical assessments of unresponsiveness are reasonable. This is why BDD cannot be approached as a recipe to be followed without a deep understanding of BDD.

While the level of evidence to support the AAN guidelines is weak, in the context of this problem, they are the most lucid and thoughtful guidelines on the topic. The weak level of evidence should not lead to abandonment of our present guidelines. Rather, it should help motivate those interested in advancing the field. Expanding scientific inquiry in key areas can bolster levels of evidence available to someday be applied to future iterations of the guidelines. The third issue raised was about the potential yet unstudied impact of "team huddles" that involve medical teams and organ procurement organizations (OPOs) in end-of-life decisions and BDD. This is a provocative comment and emphasizes the evolving importance of our commitment to the concept of decoupling (separating BDD from request for organ donation) in both clinical practice and communication with families/decision-makers. Articulating ethical boundaries to preserve integrity of the process and patient-centered decisions through the end of the patient's life is an important step in evolving in this area of clinical practice.

Until now, OPOs have taken on the task of educating physicians about BDD better than the neurologic community. They have served a vital role in helping limit the impact of widespread variability in physician confidence and experience with BDD. This variability has often sabotaged family confidence in end-of-life care and must be changed. As we take better ownership of $\mathrm{BDD}$ and prioritize evolution of our practice, the trustworthiness of the process can be preserved.

While progress in BDD has been made and is deserving of public trust, our study simply emphasized that we cannot be complacent with where we now stand. There is more work to be done.

\section{(C) 2014 American Academy of Neurology}

1. Shappell CN, Frank JI, Husari K, Sanchez M, Goldenberg F, Ardelt A. Practice variability in brain death determination: a call to action. Neurology 2013;81: 2009-2014.

2. Boly M, Sanders RD, Mashour G, Laureys S. Consciousness and responsiveness: lessons from anaesthesia and the vegetative state. Curr Opin Anesthesiol 2013;26:444-449.

3. Wijdicks EF, Varelas PN, Gronseth GS, Greer DM. Evidencebased guideline update: determining brain death in adults: 
report of the Quality Standards Subcommittee of the American Academy of Neurology. Neurology 2010;74:1911-1918.

4. Institute of Medicine (IOM) National Academy of Sciences. Clinical Practice Guidelines We Can Trust. Washington, DC: The National Academies Press; 2011.

5. Shafer TJ. Improving relatives' consent to organ donation. BMJ 2009;338:b701.

\section{HERPES SIMPLEX VIRUS-1 ENCEPHALITIS CAN TRIGGER ANTI-NMDA RECEPTOR ENCEPHALITIS: CASE REPORT}

Gordon J. Gilbert, St. Petersburg, FL: Leypoldt et al. ${ }^{1}$ reported an interesting case in which herpes simplex encephalitis (HSE) probably triggered the production of reactive NMDA receptor (NMDAR) antibodies. Within weeks of being treated with acyclovir for HSE, the patient had what the authors believed was recurrent HSE, yet it later proved to be NMDAR limbic encephalitis.

Since the viral encephalitic episode closely resembled the autoimmune encephalitic attack, it is difficult to know when the NMDAR limbic encephalitis first manifested. At initial discharge after having 3 weeks of acyclovir therapy, the patient had slow recovery, residual retrograde and anterograde amnesia, and impaired executive function. Some of these residua could have reflected the developing autoimmune encephalitis. The NMDAR immunoglobulin G (IgG) antibody level was 0 at day 1 but $1: 800$ by day 42 . These IgG levels might have become clinically relevant by week 3 of the illness. Following subsequent treatment with IV methylprednisolone, it would be interesting to know whether the patient's condition improved beyond initial discharge.

Since this is the first case reported, it is unclear how often NMDAR antibodies develop in the context of HSE. It is possible that joint use of antiviral and corticosteroid medications may become the standard for the treatment of herpes simplex virus considering the potential for NMDA antibodies to effect prolongation or recurrence of the limbic encephalitis.

Author Response: Frank Leypoldt, Josep Dalmau, Barcelona, Spain: Relapsing symptoms post-HSE usually occur within a few weeks and represent either a true viral relapse or a disorder postulated to be immune-mediated. This patient belonged to the second category. He did not have a true relapse of HSE, but anti-NMDAR encephalitis.

Our goal was to demonstrate a new synthesis of NMDAR antibodies that started after the viral infection. It is unclear whether some of the residual deficits from the first admission represented the initial manifestation of anti-NMDAR encephalitis. Only the relapsing symptoms responded to immunotherapy and this may suggest that the viral encephalitis caused the baseline deficits.

In recent studies with 6 additional patients, we confirmed that HSE can trigger anti-NMDAR encephalitis, usually between 4 and 6 weeks after HSE, but sometimes occurs without clear interval improvement of HSE. There are currently 13 patients reported with anti-NMDAR encephalitis as relapsing symptoms post-HSE ${ }^{2-5}$ and there is evidence that HSE triggers NMDAR antibodies., ${ }^{2,3}$ Most patients were children and developed choreoathetosis and dyskinesias, and immunotherapy seemed effective.

We agree that these findings may provide another reason to add steroids during treatment of $\mathrm{HSE}^{6}$ yet it is unclear whether this would prevent the development of anti-NMDAR encephalitis.

C 2014 American Academy of Neurology

1. Leypoldt F, Titulaer MJ, Aguilar E, et al. Herpes simplex virus-1 encephalitis can trigger anti-NMDA receptor encephalitis: case report. Neurology 2013;81:1637-1639.

2. Armangue T, Leypoldt F, Malaga I, et al. Herpes simplex virus encephalitis is a trigger of brain autoimmunity. Ann Neurol 2014;75:317-323.

3. Pruess $\mathrm{H}$, Finke C, Höltje M, et al. N-methyl-D-aspartate receptor antibodies in herpes simplex encephalitis. Ann Neurol 2012;72:902-911.

4. Mohammad SS, Sinclair K, Pillai S, et al. Herpes simplex encephalitis relapse with chorea is associated with autoantibodies to N-methyl-D-aspartate receptor or dopamine-2 receptor. Mov Disord 2014;29:117-122.

5. Hacohen Y, Deiva K, Pettingill P, et al. N-methyl-D-aspartate receptor antibodies in post-herpes simplex virus encephalitis neurological relapse. Mov Disord 2014;29:90-96.

6. Meyding-Lamade UK, Oberlinner C, Rau PR, et al. Experimental herpes simplex virus encephalitis: a combination therapy of acyclovir and glucocorticoids reduces long-term magnetic resonance imaging abnormalities. J Neurovirol 2003;9:118-125. 


\title{
Neurology
}

\author{
Practice variability in brain death determination: A call to action \\ Mohamed Y. Rady, Jeffrey I. Frank and Joseph L. Verheijde \\ Neurology 2014;82;2040-2041 \\ DOI 10.1212/WNL.0000000000000401
}

This information is current as of June 2, 2014

\section{Updated Information \& Services}

References

Permissions \& Licensing

Reprints including high resolution figures, can be found at: http://n.neurology.org/content/82/22/2040.full

This article cites 4 articles, 3 of which you can access for free at: http://n.neurology.org/content/82/22/2040.full\#ref-list-1

Information about reproducing this article in parts (figures,tables) or in its entirety can be found online at:

http://www.neurology.org/about/about_the_journal\#permissions

Information about ordering reprints can be found online:

http://n.neurology.org/subscribers/advertise

Neurology ${ }^{\circledR}$ is the official journal of the American Academy of Neurology. Published continuously since 1951 , it is now a weekly with 48 issues per year. Copyright @ 2014 American Academy of Neurology. All rights reserved. Print ISSN: 0028-3878. Online ISSN: 1526-632X.

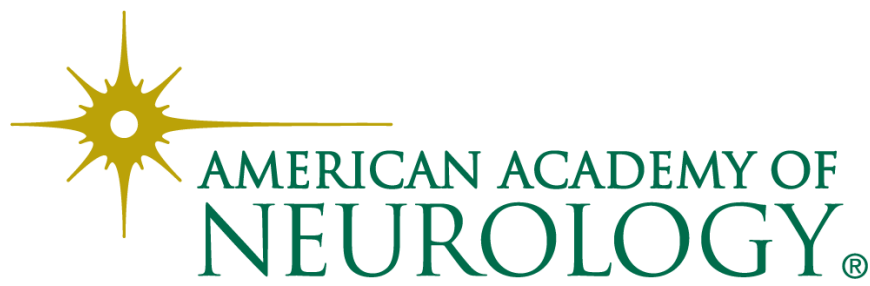

